\title{
Sustainable University Model for Higher Education in Iraq
}

\author{
Mukdad A. Al-Khateeb1, Nadhir Al-Ansari², Sven Knutsson² \\ ${ }^{1}$ University of Technology, Baghdad, Iraq \\ ${ }^{2}$ Luleå University of Technology, Luleå, Sweden \\ Email: mukdadalkhateeb@yahoo.com, nadhir.alansari@ltu.se, sven.knutsson@ltu.se
}

Received 14 February 2014; revised 14 March 2014; accepted 20 March 2014

Copyright (C) 2014 by authors and Scientific Research Publishing Inc.

This work is licensed under the Creative Commons Attribution International License (CC BY). http://creativecommons.org/licenses/by/4.0/

c) (i) Open Access

\begin{abstract}
Education can become another burden on the development unless addresses the internal, external and natural challenges by Sustainable Universities that provide an educational, cultural and teaching model through a sustainable development strategy. This paper tends to illustrate the different challenges of sustainable development in Iraq coupled with the full ignorance of the concept and principles of sustainability and suggests a model for a sustainable university. Although the suggested model is rather complicated, but it is crucial to encompass the different effects of human resources on the sustainable development capitals, at and beyond, the university campus.
\end{abstract}

\section{Keywords}

Sustainable Development; Iraq; Sustainable Universities; Sustainable Development Strategy

\section{Introduction}

Education is expected to fulfill the humans' needs and confronts the challenges facing their livelihood, at present and future, through the full accomplishment of the Millennium Development Goals (MDGs). Sustainable development (SD) is development that meets the needs of the present generations without compromising the ability of future generations to meet their own needs (Brundtland Report, 1987). Accordingly, education becomes worthless, unless complies with the context of SD and guides the community to the psychological and livelihood stability. Creating solutions and finding new paths to a better future is determined by today's education and its ability to prepare leaders and citizens (UNESCO, 2013).

Universities should have the advantage of delivering the best knowledge that should demonstrate the excellent solutions for the social, economic and environmental challenges through shaping the mentality of the university's academic staff and students; usually at youth age. This case persistently draws back with the lack of "sus- 
tainable development” proficiency among: academic staff, curriculum, on-site practices, research, and students; the factors that formulate a "Sustainable University".

The University's Sustainable Development Strategy (USDS) comprises the action plans, set at the university, to deliver the interactions between the human resources and the three SD capitals; natural, human \& social, and built capital, in favor of sustainable consumption and production, zero-waste, minimizing greenhouse gas emissions (GHGs), social equity and promoting innovation capacity. Different USDS models have already been suggested worldwide by several universities, reflecting the desires and needs of each university in promoting its ambitions and developmental trajectories. In almost all the developed and very few developing countries, the constitutions and regulatory rules usually manage the human-human and human-social relations and accordingly wouldn't be of interest to the USDS. Other universities might find their procurement procedures worth concentrating on, while most USDSs concentrate on the University's Campus Sustainability. In general, the USDS reflects the perquisites for a better sustainability values: social, economic and environmental, whenever needed.

Iraq, previously known as Mesopotamia — the land between the rivers—-for it embraces a large part of the alluvial plains of the Tigris and Euphrates rivers, is presently a developing country ranked internationally amongst the highest in oil reserves. Managing this wealth is a great challenge and requires a sustainable development strategy that wouldn't possibly be effective unless supported by "Education for Sustainable Development".

This paper tends to illustrate that the ongoing education is incapable to confront the challenges of sustainable development in Iraq and suggesting an Iraqi model for a "Sustainable University" that would, even if partially, mitigate the current failures in which the education should be for the preparation of sustainable development, human and technological capacities.

\section{Method}

To illustrate the different challenges of sustainable development; to make the inefficiency of education in general and particularly in higher education; to confront those challenges. Also, suggesting a model for a sustainable university that would suite most Iraqi universities, with the full recognition of the needs for further amendments by each university depending on the potentials and surrounding circumstances.

\section{Brutal Challenges}

Scientific standard of Iraqi universities was at the top of the Middle East region till 1980. Once the first Gulf war started (1980) the standard was declining. There were several reasons for that decline. The students had no motives to study, simply because they were reluctant to go to the war front. Furthermore, university staff members were not allowed to communicate with their counter partners abroad. The situation became worse in 1990 when UN sanctions were imposed on Iraq. During this period, universities had no new equipment and even they could not maintain the old equipment they had. They were also completely isolated. Several countries, asked the Iraqi students doing their postgraduate studies abroad to abandon their research and go back to Iraq. As a counter measure, the Iraqi government at that time asked to increase the number of postgraduate students and tremendous number of students was accepted on the master and doctorial levels. These students did their research using old equipment and out of date techniques and methodologies. As a consequence, after 12 years of sanctions and about 23 years of war this deprived the educational sector from upgrading its technological and staff performance. The situation became more devastating when those students got their degrees and appointed as staff members at different universities. They form the majority at the present time. Having such staff, development is almost impossible.

After 2003, the situation did not improve. Regardless of the motives, invading Iraq in April 2003 has severely affected the sustainable development capitals. Most of the intellectuals fled the violence and threats, the infrastructure was demolished, industries completely halted, millions were forced to leave their homes seeking safe haven, security and military institutions dismantled and worst of all, the domination of sectarian and ethnic, mentality and attitudes. Each of those has had some share in a full cost that had to be paid by the natural capital; natural resources, ecosystems and natural beauty.

The latest official (governmental) population census was accomplished in 1997 (Ministry of Planning, 2010a $\&$ b). Most recent resources estimate the Iraqi population to range between 31.7 million (IKN, 2011) and 32,961,959 (World Bank, 2011). The most impressing demographic phenomenon in Iraq is the "Youth Bulge"; when the less than 24 years age group numerically dominates the population, estimated to be $61.7 \%$ and ex- 
pected to see rapid growth over the coming years (NATO, 2010). In addition, 57\% of the age group 15 years and above believe to be economically inactive, (78\%) of them are females because they are housewifery, whereas the males' decline to work. This is attributed to; educational disqualification (53\%), age (13\%) and/or disability and sickness (7\%) (IKN, 2011). As for the Iraqis living standards, 23\% of Iraq's population lives below the poverty line with an average expenditure of US \$2.2 per capita per day (World Bank, 2007), whereas the population growth rate ranges between 2.345\% (2012 est.) (CIA, 2013), while it was 2.7\% (2005 est.) (About.com, 2013). Most recent UNDP Report on the MDGs in Iraq, shows that the people with less than $2.5 \$$ day income declined from 13.9\% in 2007 to $11.5 \%$ in 2011 and the Gross Domestic Product per Capita increased from 0.8\% to $2.1 \%$ for the same years. Still, the unemployment rate among the Youth population (15 - 24 years), dropped so little from $30 \%$ in 2008 to $22.8 \%$ in 2011 and being mostly employed (40\%) by the government and public sector while the remainder distributed between private and informal sectors (2015 Millennium Development Goals, UNDP, www.iq.undp.org). These figures suggest that; Iraq should be prepared to accommodate at least 55 million Iraqis in 2030, rising up to 83 million in 2050 (Population Pyramid of the World, 2013). It might worth mentioning that it is entirely difficult to get credible data about Iraq. The expected vague and even sometimes controversial, data is attributed to the lack of statistics and information, confidentiality and security measures, and transparent data base deficiency. In all cases, this unavailability of data and resources mostly drives to the dependence on the available, yet credible, UN agencies' reports, publications and bulletins and trustworthy internet web sites.

The Climate Change and the GAP project in Turkey has already affected Iraq through; the scarcity and shortage of water supply, high temperature norms, frequent sand and dust storms and consequent land degradation, which can be the direct (Al-Ansari, 2013; Al-Ansari et al., 2012), but not the sole, reason for the undernourishment among the Iraqis. Seven out of every 100 Iraqi individuals are undernourished, which is equivalent to an estimated 2.1 million Iraqis. At the level of household characteristics, food deprivation; defined as the number of people whose daily dietary energy intake is lower than the minimum dietary energy requirement (MDER), is concentrated within population groups of low income and large families, whose sponsor is over 50 years of age and also illiterate mainly involved in agricultural activities or unemployed (Ministry of Planning, 2010a). The population consuming less than the recommended daily energy intake, has dropped only $1 \%$ to record a national rate of $6 \%$. However, some provinces have much higher rates. Although underweight children under the age of five decreased from $15.9 \%$ in 2000 to $8.4 \%$ in 2011, some provinces still face high rates of food deprivation (2015 Millennium Development Goals, UNDP, www.iq.undp.org).

Climate change will continue to affect Iraq making it vulnerable to natural disasters and environmental challenges. Although the drought has retreated since 2009, Iraq is still attempting to recover from its effects (AlAnsari, 2013). Despite the fact that drought has receded since 2009, Iraq is still attempting to recover from its effects (ITCC \& ISDR, 2008). Almost 40\% of cropland throughout Iraq between 2007-2009, witnessed reduced crop coverage (FAO AQUASTAT, 2009) and livestock was demolished. The situation forced 20,000 rural inhabitants to leave their habitat in search of more sustainable access to drinking water and livelihoods. Similar occurrences in the future will further increase the pressure on the urban water systems and economy.

Iraq, is the inheritor of the historically oldest ever known civilization. Mesopotamia, the land between the two rivers (Tigris and Euphrates), unfortunately, presently relies on precipitation falling outside its borders for more than half of its water supply, making them vulnerable to climate change and storage projects in Turkey, Syria and Iran (Al-Ansari, 2013; FAO AQUASTAT, 2009). The availability of water is considered to be moderate, estimated at $2400 \mathrm{~m}^{3}$ per person per year, suggesting that with exception of Turkey, Iraqis have more water than their neighbors (FAO, 2010), and still, levels of surface water in the reservoirs, lakes and rivers are diminishing to critical levels as a result of the poor management of water resources. This also applies to groundwater aquifers their recharge has impacted to level and quality of groundwater supplies. Tigris and Euphrates Rivers, although being the primary sources of surface water, are suffering of fallen discharge rates and are already declining to less than a third of normal capacity and expected to drop further in coming years (Al-Ansari, 2013; IAU, 2012).

Geographically, one third of the Iraqi surface is a desert, and yet, years of inappropriate farming and mismanagement of water resources in addition to the climate change, have increased the soil salinity and erosion, extended sand dunes and accordingly declining the land fertility (Al-Ansari, 1998; Al-Ansari et al., 2012). The Government of Iraq reports that 28\% of the country's land is arable (Iraqi Ministry of Environment, 2010) of which an average of 100,000 donum (1 donum in Iraq is equal to 2500 sq. m., or 0.4 hectares) is lost each year 
to degradation (The Currency Newshound, 2013). Meanwhile 39\% of the country's surface is estimated to have been affected by desertification, with an additional 54\% under threat (Iraqi Ministry of Environment, 2010). The lack of vegetation cover has resulted to frequent unprecedented vast dust and sand storms. IAU (2011a), causing significant disruptions in transportation systems in Iraq and result in hundreds of Iraqis seeking medical help, suffering from choking, eye problems and increased incidence of asthma attacks (UNDP, 2010). The variability of the country's climate, especially in terms of water supply, could be better exposed when knowing that the two years of severe drought between 2007 and 2009 were followed by several months of sudden heavy rainfalls and storms during which some parts of central and southern Iraq experienced rainfall amounts about $200 \%$ of normal values IAU (2011a). As a conclusion, Iraq's environment was ranked 132 among 132 countries according to the 2012 (EIA, 2013).

The successive wars (1980-2003) and the sectarian and ethnic conflicts afterward, have resulted to another version of land degradation. Internally displaced immigrants had to move to safe havens mostly at the perimeter of the cities. Although such areas are mostly deserted and lacking the required infrastructure, but they still mostly arable. The immigrants could survive only at the cost of land degradation and ecosystem's carrying capacity for they relied on the surrounding environment to provide their daily living-needs and consequently establishing new unqualified residential areas that had added another burden to the already inefficient infrastructure and basic services as much as degrading the land that should have been invested for; agriculture and the enhancement of food security.

Iraq experienced two wars in 1991 and 2003, during which massive amounts of Depleted Uranium weapons (DU) was severely used. As a consequence of the radioactive contamination, the humans are suffering from various diseases like cancer and are polluted environment (Al-Ansari, 2011; Al-Almuqdadi \& Al-Ansari, 2011a \& b; Al-Ansari et al., 2014).

DU was used twice by the Americans and allied forces against Iraqi troops and personnel in 1991 and 2003. The largest single radionuclide contamination occurred in 1991, where DU was used as armor-penetrating ordnance, contaminated the countryside of Iraq, and chronically exposed the civilian population and military personnel to DU dust, vapors, and aerosols.

During the second Gulf war in 2003, US and British troops have reportedly used more than five times as many DU bombs and shells as the total number used during the 1991 war for the invasion and occupation of Iraq. It was estimated that more than 1100 to 2200 tons of DU was used. This quantity is 400 to 800 more powerful than the ones used in the first Gulf war. According to Okinawa (Al-Muqdadi, 2007), every 800 tons of DU is equivalent to 83 nuclear bombs. Accordingly, about 250 nuclear bombs were fired on Iraq till 2003 war.

Weyman (2003) reported that the Uranium Medical Research Center cited in their report that the published data about the quantities of DU used in Iraq are as follow:

1) 24 Imperial Tons (21.8 Metric Tons). US Army data related by US Senator Jon Kyle, US Senator, Chair of the Republican Policy Committee, in a letter to J. Cohen-Joppa, July 14, 2003.

2) 100 - 200 Metric Tons-D. Fahey, the Use of DU in the 2003 Iraq War: An Initial Assessment of Information and Policies, June 24, 2003.

3) 68 Metric Tons (75 Imperial Tons), representing calculations based on \% of DU rounds loaded in total fired rounds of 300,000 by A-10 Thunderbolt. Reported interview of unnamed CentCom spokesperson, Christian Science Monitor, May 15, 2003.

4) 311,597 30-mm rounds, T M Mosley, USAF, By the Numbers, Operation Iraqi Freedom, Assessment and Analysis Division, USAF, April 2003.

5) 1000 - 2000 Metric Tons (1100 - 2200 Imperial Tons), posted in Associated Press article, The Environment in the News, UNEP Environmental Press Release Reports, Communications and Public Information, United Nations Environment Program, Associated Press, April 2003.

Scherrer (2003), based on the report of the 48th meeting issued by the UN Committee dealing with effects of atomic radiation on 20th April 1999, noting the rapid increase in mortality caused by DU between 1991 and 1997, the IAEA document predicted the death of half a million Iraqis, noting that “...some 700 - 800 tons of DU was used in bombing the military zones south of Iraq. Such a quantity has a radiation effect, sufficient to cause 500,000 cases which may lead to death.”

Iraq's economy is exclusively unilateral where oil industry dominates the Iraqi economy, contributing to $60 \%$ of GDP, 99\% of exports and over 90\% of Government revenue (IAU, 2011b). Iraq's estimated average oil production in July and August 2012 was around 3.1 million bbl/d (TechCorr, 2012) after used to be an average of 
2.4 million bbl/d throughout 2009-2011 whereas Iraq consumed 694,000 million bbl/day in 2010 (CIA, 2013). These high oil exploitation processes ranked Iraq as the 37th largest pollutant among 217 countries, and responsible for 104 million tons of emitted $\mathrm{CO}_{2}$ (EIA, 2013) in 2009, out of the world CO2 total emission estimated to be 30,389 million tone (EIA, 2009). Oil, the depleted natural resource, which should be wisely invested for the achievement of the MDGs is being mismanaged and mostly wasted. Despite the high revenues gained from Oil, estimated at 2011 to be around 67 billion USD, the national expenditure was 85 billion USD, 73 \% of which to cover the running cost (mainly salaries) and only $27 \%$ dedicated for investment (Al-Anbagy et al., 2011).

\section{Inefficient Education}

Prior to 1980, The Education system in Iraq, was marked as one of the best and recognized as the most advanced in the region, expressing strong national vision and strident and idealistic leadership, moreover had become free and compulsory in 1976 (Geopolicity, 2009). Prior to 1991, the Gross Enrolment Rate for primary schooling was over $100 \%$ accompanied by high levels of literacy, both of men and women. The international standard and highly qualified personnel fingerprinted the Higher Education, especially the scientific and technological institutions (UNESCO \& IRAQ, 2003). The years (1991-2003) witnessed an international embargo that resulted to a great deterioration in the education system as a result of the deficiency in the daily living needs. School attendance decreased drastically as education funding was cut and the scarce income forced children into the workforce (Wikipedia, 2003). According to UNESCO's 2003 Situation Analysis of education in Iraq, the educational system in the Centre/South worsened despite the provision of basics through the Oil for Food Programme (UNESCO \& IRAQ, 2003), while the North (Kurdistan-Iraq) did not suffer as much due to rehabilitation and reconstruction programs executed through UN agencies.

The education after 2003 invasion, suffered another version of deterioration. The Iraqi Ministry of Higher Education reported that over 3250 academics had fled the country between February and August 2006. According to the Iraqi Association of University Lecturers about 300 academics, including Ph.D.’s working in Iraqi government ministries and university administrators, had been killed before January, 2007 (Wikipedia, 2003). The extent of the violence against academics has prompted fears of a "brain drain" in Iraq of those academics who are not killed and accordingly the UNESCO director-general Koïchiro Matsuura spoke out loudly saying; "By targeting those who hold the keys of Iraq's reconstruction and development, the perpetrators of this violence are jeopardizing the future of Iraq and of democracy" (AAAS, 2013).

The enrollment of children in primary education rose from $76.3 \%$ in 2000 to $89.1 \%$ in 2011, but disparities continue to persist amongst males and females, as well as between urban and rural areas. Eliminating gender disparity at all levels of education will help increase the status and capabilities of women. Unfortunately, as a result of cultural and social factors, gender equality is not expected to be achieved in Iraq by 2015 (2015 Millennium Development Goals, UNDP, www.iq.undp.org).

In principle, education is a fundamental human right which should be directed to the full development of the human personality (UN, 2013). Despite the drop in net primary school enrolment rates from 91\% in 1990 to 85\% in 2007, Iraq still faces challenges in its progress to meet the 2015 target of $100 \%$ net primary enrolment. Equal enrolment rates for girls and boys (MDG Three, EFA Goal Five) have nearly been detected in urban areas (99\% girls-to-boys net primary enrolment ratio), but still, the rural areas suffering that the already-low enrollment rate of 77\% has dropped to 70\% among girls (UN, 2013; World Bank, 2007).

Sustainable development provides the opportunities for establishing Sustainable Communities and promotes social equity as much as environmentally efficient economy. Education in Iraq is still developmentally retarded and unable to confront the challenges of sustainable development, which should be the main goal for every education system. A questionnaire distributed, in 2009, amongst a random sample of the first year's university undergraduates at the University of Technology, Baghdad, revealed that $91 \%$ have had never heard of the expression "Sustainable Development" (Shanableh, 2010; Al-Khateeb, 2010a \& b). Later, in 2010, another survey for 4th year secondary school students (equivalent to grade 10) at four secondary schools, East Baghdad, illustrated that 96\% of those students have had heard so little or not at all of "SD" (Shanableh, 2010; Al-Khateeb, 2010a \& b). In both cases, the education system has failed to deliver, not only the concepts and principles of SD but even the expression itself. What worsened the situation is the 2012 survey, when 95\% of 4 departments' academics at the University of Technology stated that they had no idea at all about what Sustainable Development is (Mohammed, 2012). Also, throughout several personal (meetings, conferences, workshops and interviews) the fact that SD is a forgotten phrase was so obvious, whereas on the ground, neither the politicians nor the media men- 
tion "SD" except at very occasional circumstances, reflecting the general conditions of total SD, neglect and carelessness.

\section{The Sustainable University: Iraqi Perspective}

The education today defines tomorrow's generation abilities to explore their trajectories to a better and secure future. Sustainable development requires a special kind of education that ensures providing the knowledge for the citizens to learn their way to sustainability: enabling the community to explore, mitigate and/or adapt the current and future, national and global, environmental, societal and economic challenges.

Despite the need for long term SD-Enabling Strategies, the universities' undergraduates urgently need short term and rather instantaneous action for they represent the possible developmental alterations of the very near future. They should be aware of the ongoing exploitation rates of SD Capitals (natural, human and social, and built) through the current livelihood and related unsustainable consumption and production patterns.

Universities have commitments towards sustainable development arising from:

1) Being a premises (public/governmental) with specific need for energy and natural resources to maintain the living of the inhabitants (staff and students) and consequently emitting wastes (liquid, solid and gas).

2) Being an educational institute where considerable numbers of academics, students and other employees should get practiced to the echo-efficient living patterns and also educate the community of the importance of such patterns for their present and future generations.

3) Being a learning compound where general knowledge and basic sciences should be equally delivered by the teachers to the students.

The Iraqi SD-University model could rather be confusing to those living in developed countries, for it has to deal more deeply with the "Human and Social Capital" through the human needs, working requisites, behavioral manners and social relations in addition to the environmental sustainability, and "Built Capital" preservation.

\section{Iraqi Model of a Sustainable University}

The effective SD human elements on sustainable development at the Iraqi universities are (Figure 1):

1) Vice Chancellor (normally called the President of the University) and the University Board.

2) Academic Staff.

3) Administration Staff.

4) Students (post and under graduates).

The collaboration amongst the effective SD human elements is essential to maintain the various sustainable development trajectories at all SD-Capitals (Natural, Human, Social and Built). Accordingly, the SDS of any Iraqi University should bring into details all the relevant action plans of every procedure to preserve each capital as shown in Figure 1; explaining the measures that should be taken for mitigation or adaptation, execution interval, monitoring and evaluation of the following themes:

1) Environmental Sustainability;

2) Working Environment;

3) The Student;

4) Corporate Social Responsibility.

It is noteworthy to state that implementation of this model should take into consideration all the problems mentioned earlier. To do so, is not simple and requires strong cooperation with the Ministries of Education and Environment and perhaps others.

\section{Discussions and Conclusions}

Sustainable development secures the livelihood of the present as well as the coming generations, thus becoming related to the daily living patterns and personal behaviors. Today's habits and lifestyle are certainly inherited from our ancestors and will be imitated by generation after, to become living styles, therefore need to be adjusted to fulfill the ecosystem's carrying capacity and the need for sustainable consumption and production.

In spite of Iraq's wealth, its efficient utilization needs significant upgrading and improvements. The performance of industry has significantly deteriorated over many years of wars and sanctions then worsened after 2003. The Industry infrastructure is either destroyed or inefficient and costly to operate. Industry improvement will not only require new equipment but most importantly, needs a human capital that is capable of conducting 




Figure 1. Effective SD human elements on sustainable development at the Iraqi universities.

the reconstruction process which can lead to the efficient utilization of the resources. The latter can only be met by continuous education and training on the latest developments and management practices including advanced IT, as it can bring about efficiency and quality.

Sustainable development is only achieved through the investment of the SD capitals (Figure 2); natural, human and social, and built into MDGs through the full synchronization of the sustainability wheels; good governance, innovated technology and SD-educated community. This process (alteration of SD Capitals to MDGs) needs highly qualified educated university graduates; experts and planners, which are aware of the domestic and international challenges, of the sustainable development in Iraq and accordingly set their strategies. The gap between the education and the realities is the main reason for the inefficiency in education and this is the case where education becomes another burden on development rather than pushing it forward.

Although Iraq has a very large number of University graduates in different specializations, the country has been denied the normal technical exchange between countries which has had a terrible impact on Iraq's educational and training infrastructure. This state of affairs has quickly brought down the quality of higher and continuous education to a point where it is impairing the capacity of the younger generation to rebuild their civil and democratic society. In order to enable this generation to rebuild the country's economy and restart the development process, it is of a paramount importance to upgrade and re-skill the existing Iraqi planners. This should involve upgrading the skills of new Iraqi graduates and retraining existing professionals.

The majority of the Iraqi population is of youth age (15 - 24 years) that constitute $19.6 \%$ of the population which is already blessed by a 56.8\% "Youth Bulge" (Figure 3) (CIA, 2013), suggesting a great opportunity for Iraq to build up its human resources' capacity based on the fundamentals of sustainable development through ESD "Education for Sustainable Development”; a kind of education that (UNESCO, 2013):

- is based on the principles and values that underlie sustainable development;

- deals with the well-being of all four dimensions of sustainability-environment, society, culture and economy;

- uses a variety of pedagogical techniques that promote participatory learning and higher-order thinking skills;

- promotes lifelong learning;

- is locally relevant and culturally appropriate; 


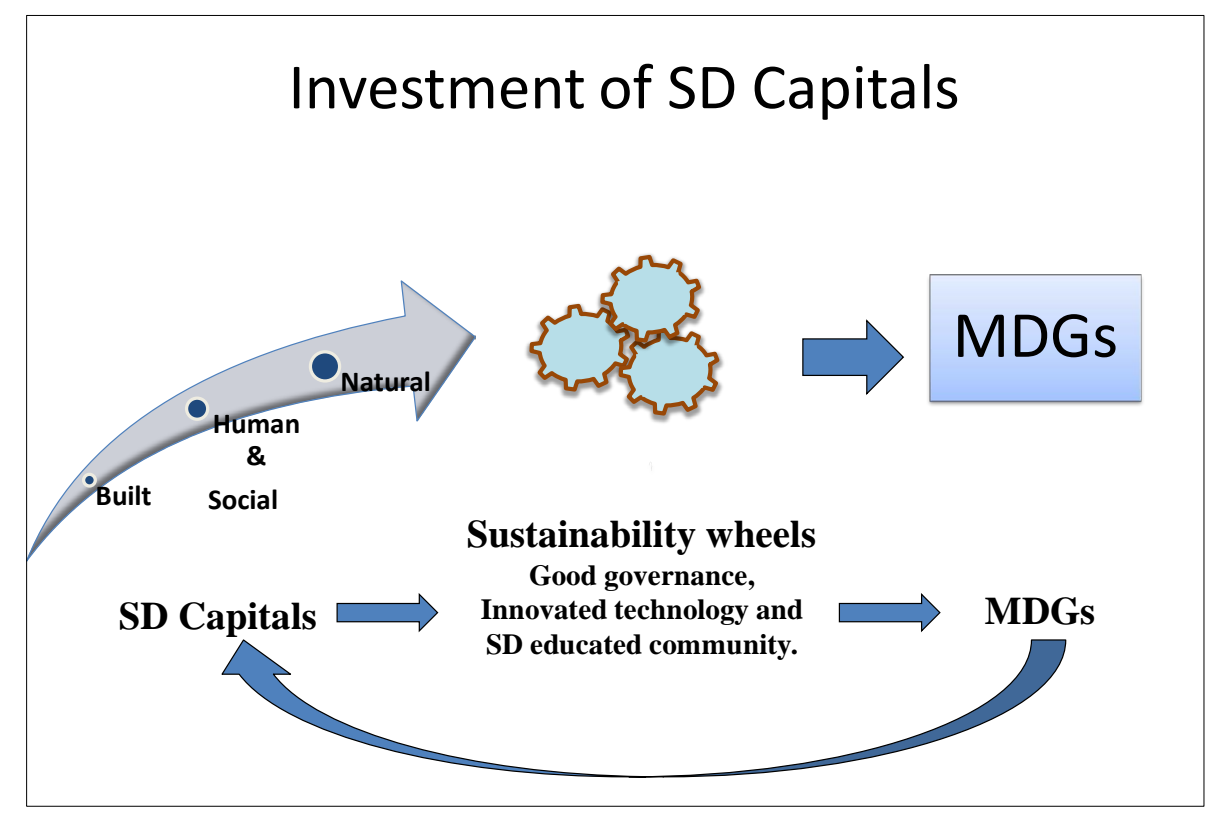

Figure 2. Effective SD human elements on sustainable development at the Iraqi universities.

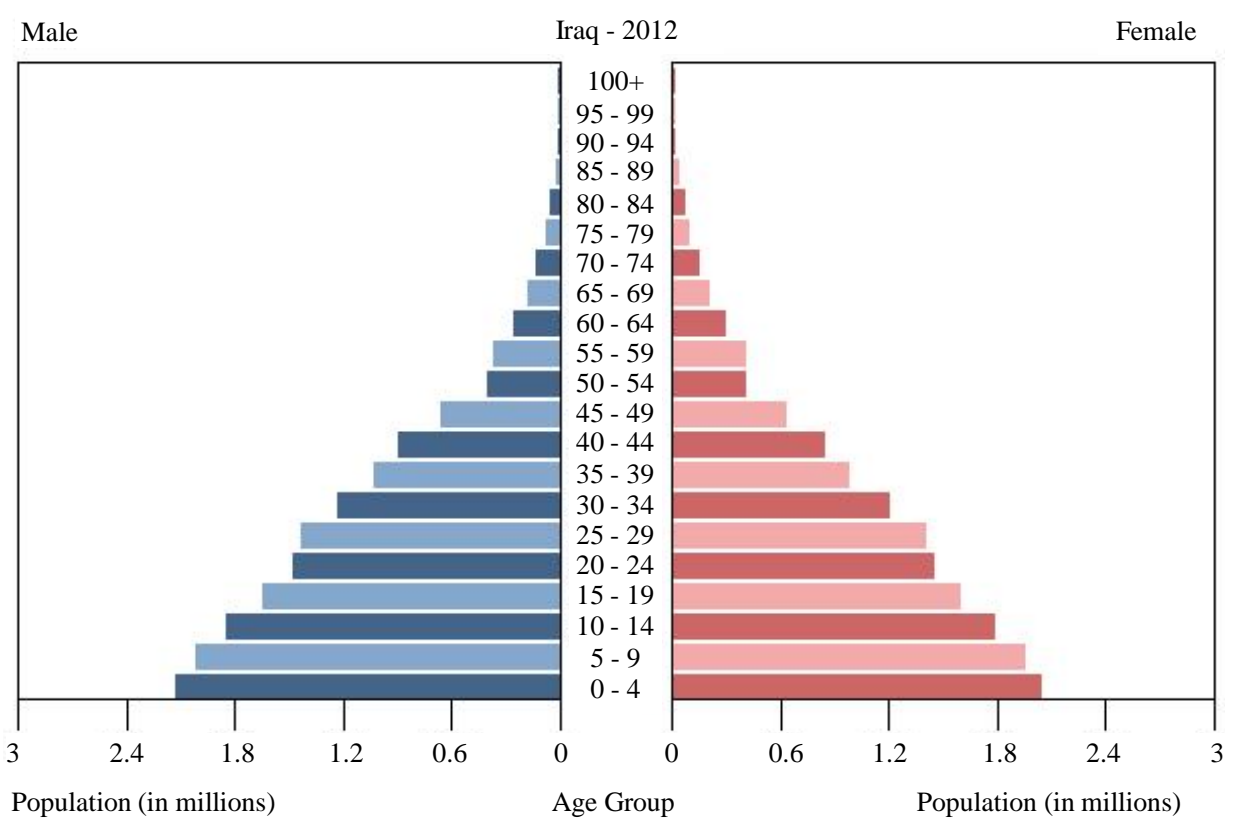

Figure 3.Youth demography in Iraq 2012.

- is based on local needs, perceptions and conditions, but acknowledges that fulfilling local needs often has international effects and consequences;

- engages formal, non-formal and informal education;

- accommodates the evolving nature of the concept of sustainability;

- addresses content, taking into account context, global issues and local priorities;

- builds civil capacity for community-based decision-making, social tolerance, environmental stewardship, an adaptable workforce, and a good quality of life;

- is interdisciplinary. No single discipline can claim ESD for itself; all disciplines can contribute to ESD.

"Education for SD" is the only education capable of harmonizing the personal interest with the community's goals in becoming a "Sustainable Community" (SC); that is economically, environmentally, and socially healthy 
and resilient. SC meets challenges through integrated solutions rather than through fragmented approaches that meet one of those goals at the expense of the others and takes a long-term perspective-one that's focused on both the present and future, well beyond the next budget or election cycle (Institute of Sustainable Communities, 2013).

The universities could contribute to ESD through curriculum, research, and activities (projects, forums, lecture, etc.) where the academic staff and students share their ideas and explore initiatives that would mitigate/ adapt the different challenges resulting to a "Sustainable University" that should provide the opportunities for the best sustainability practices through a "Sustainable Development Strategy" (SDS) that encompasses different action plans that would demonstrate the best procedures to safeguard the natural capital, build up the human and social capital, and also preserve the built/financial capital. Although the Iraqi model of a "Sustainable University" might be rather complicated and abnormally exclusive, but the need for such model is essential to illustrate the role of the universities in the investment of SD capitals through the knowledge and practices, especially in the light of neglect to the principles of "Sustainable Development" amongst the academic staff and students coupled by the underestimation of the importance of human/social perquisites for knowledge upgrading, innovation and invention.

The Iraqi model for a sustainable university should demonstrate the interactions between the human resources and the SD Capitals at the University through four "Themes"; Environmental Sustainability, Working Environment, Student and Corporate Social Responsibility (Figure 1). Each theme contributes in developing and safeguarding the "Elements" of SD capitals and relating the university to the community and government.

Environmental Sustainability should secure; the sustainable consumption of water and energy, controlling air pollution, waste recycling practices and procedures, distribution of green areas, lowering noise pollution and taking adaptation/precautionary measures for natural hazards.

The most extraordinary theme, to be dealt with in every SDS is the Working Environment, as it should demonstrate the mutual beneficial relations between the human resources and the university as an entity and present a kind of inter and intra relation between the "Effective Sustainable Development Human Elements" and secure their comfort. This theme is not usual in north countries' sustainable development strategies, as such behaviours/relations are regular, procedures and habits amongst the community, while the comfort needs are well served and dominant.

Student's social performance is also important. It should be adjusted to overcome the destructive sectarian mentalities through educational practices and meetings that would divert the students' behaviour and thinking towards means of achieving sustainable development.

The relation with community is an essential part of the University's SDS. The CSR should be illustrated through engaging the university with the NGOs, encouraging voluntary work to help the community and sharing social and scientific plans and projects with the surrounding community. All the above, requires prudent long term strategic planning to achieve all these goals. Such plan should take into consideration all aspects of the university environment plus pre-university education otherwise it will hardly achieve the required goals.

\section{Conclusion}

Iraq had suffered from various wars and sanctions before 2003. After that, the country is facing other problems (e.g. water shortages, desertification, etc.). All these complicated problems had affected the educational system in the country especially on the universities level. To retain the scientific standard it is believed that human resource development is to be the first goal to be achieved. This can be achieved through the educational institutions in particular the universities. Sustainable university model can be the first important step to be taken.

Sustainable university in Iraqi should demonstrate the interactions between the human resources and the SD capitals at the university through four "Themes": Environmental Sustainability, Working Environment, Student and Corporate Social Responsibility. Each theme contributes in developing and safeguarding the "Elements" of SD capitals and relating the university to the community and government. It should be stressed that such SD program should take into consideration all the existing and looming problems facing Iraq. Experience of other countries as well as educational institutions like UNESCO is to be also considered.

To achieve this goal, long term planning program is to be adopted. Such planning should also consider preuniversity educational programs so that students entering the universities will be ready to be enrolled automatically within the SD program. Then university graduates will be ready to enter the practical life and they are aware of the problems they are going to face. 


\section{References}

AAAS (2013). Threatening and Killing of Scientists in Iraq. http://shr.aaas.org/emerging_issues/iraq.htm

About.com (2013). Geography, Iraq. http://geography.about.com/library/cia/blciraq.htm

Al-Anbagy, A., Aljebouri, H., \& Alshalal, M. (2011). Analysis of the Budget (2011) in Iraq and the Extent of Their Consistency with the National Development Plan for the Years 2010-2014, Introduction to the Study of the Advisers in the Province of Babylon(in Arabic).

Al-Ansari, N. A. (1998). Water Resources in the Arab Countries: Problems and Possible Solutions. UNESCO International Conference (Water: A Looming Crisis), Paris, 367-376.

Al-Ansari, N. A. (2011). Landfills in Arid Environment. Key Note Paper, Specialized Workshop on Landfills of Hazardous Waste and Its Implications on Health and Environment, 15-17 November 2011, Lulea: Lulea University of Technology.

Al-Ansari, N. A. (2013). Management of Water Resources in Iraq: Perspectives and Prognosis. Journal of Engineering, 5 , 667-684.

Al-Ansari, N. A., Knutsson, S., \& Ali, A. (2012). Restoring the Garden of Eden, Iraq. Journal of Earth Sciences and Geotechnical Engineering, 2, 53-88.

Al-Ansari, N. A., Knutsson, S., \& Almuqdadi, K. (2014). Engineering Solution for Radioactive Waste in IRAQ. Journal of Advanced Science and Engineering Research, 4, 18-36.

Al-Khateeb, M. (2010a). The Participation of High Education in the Instantaneous Preparation of Sustainable Development Human Resources. 5th IFEE 2010 (Fifth International Forum on Engineering Education). Paperno: UAE.

Al-Khateeb, M. (2010b). Sustainable Development in Iraq. J. Altanmiya, 26, 24-38.

Al-Muqdadi, K. (2007). When Cleaning Radioactively Contaminated Sites in Iraq? Environment \& Development, $112 / 113$.

Almuqdadi, K., \& Al-Ansari, N. A. (2011a). The Waste of Wars in Iraq: Its Nature, Size and Contaminated Areas. Specialised Workshop on Landfills of Hazardous Waste and Its Implications on Health and Environment, 15-17 November 2011, Lulea: Lulea University of Technology.

Al-Muqdadi, K., \& Al-Ansari, N. A. (2011b). The Waste of Wars in Iraq: Its Nature, Size and Contaminated Areas. Specialized Workshop on Landfills of Hazardous Waste and Its Implications on Health and Environment, 15-17 November 2011, Lulea: Lulea University of Technology.

Brundtland Report (1987). “Towards Sustainable Development” in Our Common Future (pp. 43-66). Oxford: Oxford University Press.

CIA (2013). Middle East: Iraq. https://www.cia.gov/library/publications/the-world-factbook/geos/iz.html

EIA (2009). An Atlas of Pollution: The World in Carbon Dioxide Emissions. http://image.guardian.co.uk/sys-files/Guardian/documents/2011/02/10/CarbonWeb.pdf

EIA (2013). The Availability and Price of Petroleum and Petroleum Products Produced in Countries Other Than Iran. http://www.eia.gov/analysis/requests/ndaa/pdf/ndaa.pdf

FAO (2010). Review of Water Resources Statistics by Country, Iraq. http://www.fao.org/nr/water/aquastat/countries_regions/iraq/index.stm

FAO AQUASTAT (2009). Computation of Long-Term Annual Renewable Water Resources, Iraq. http://www.fao.org/nr/water/aquastat/data/wbsheets/aquastat_water_ba12,1lance_sheet_irq_en.pdf

Geopolicity (2009). Iraq Education Sector, Scoping Study. http://www.geopolicity.ae/upload/content/pub_1288013876_regular.pdf

IAU (2011b). Oil and Gas Factsheet, Iraq. http://iq.one.un.org/documents/327/Oil\%20Factsheet\%20-\%20English.pdf http://www.techcorr.com/news/Articles/Article.cfm?ID=3862

IAU (2012). Climate Change in Iraq Fact Sheet, June 2012. http://iq.one.un.org/documents/468/Climate\%20change\%20In\%20Iraq\%20Fact\%20sheet\%20-\%20English.pdf

IAU (Inter-Agency information and Analysis Unit) (2011a). Water in Iraq Factsheet. http://iq.one.un.org/documents/161/Water\%20Fact\%20Sheet\%20March\%202011.pdf

IKN (2011). Iraq Knowledge Network: Labour Force Factsheet-December 2011. http://reliefweb.int/report/iraq/iraq-knowledge-network-labour-force-factsheet-december-2011.

Iraqi Ministry of Environment (2010). Report of the Ministry for the Environment For the Year Ended 30 June 2010. http://www.mfe.govt.nz/publications/about/annual-report/2009-2010/index.html

ITCC, \& ISDR (The Informal Taskforce on Climate Change of the Inter-Agency Standing Committee and the International Strategy for Disaster Reduction) (2008). Disaster Risk Reduction Strategies and Risk Management Practices: Critical Elements for Adaptation to Climate Change. http://www.refworld.org/publisher,IA,,,4a2d189d10,0.html 
Ministry of Planning (2010a). Food Depravation in Iraq. http://reliefweb.int/report/iraq/food-deprivation-iraq

Ministry of Planning (2010b). Five Years National Plan 2010-2015, Republic of Iraq, Ministry of Planning, National Development Plan 2010-2014.

Mohammed, L., Badri, S., Samih, S., \& Hussien, Y. (2012). SD Strategy of the University of Technology, SD Committee at the University of Technology, Internal Report.

NATO (2010). Parliamentary Assembly, Mediterranean and Middle East Special Group. http://www.nato-pa.int/default.asp?SHORTCUT=2342

Population Pyramid of the World (2013). Iraq 2020. http://populationpyramid.net/Iraq/2030/\%29./

Scherrer, C. (2003). DU and the Liberation of Iraq. Christian Scherrer's ZSpace Page http://www.zcommunications.org/du-and-the-liberation-of-iraq-by-christian-scherrer,Life

Shanableh, A. (Ed.) (2010). 5th International Forum on Engineering Education (IFEE2010). http://www.scribd.com/doc/120060740/International-Forum-on-Engineering-Education-IFEE-2010-Book-of-Abstracts

TechCorr (2012). The Availability and Price of Petroleum and Petroleum Products Produced in Countries Other Than Iran, August 24, 2012.

UN (2013). The Universal Declaration of Human Rights. https://www.un.org/en/documents/udhr/

UNDP (2010). Climate Change Programme, Climate Change Workshop 2010. http://www.ccalb.org/editor-files/file/MSP\%20Project/Minutes_of_the_Second\%20risk\%20assessment\%20workshop_Lez he maj 2010.pdf

UNESCO (2013). Education for Sustainable Development.

http://www.unesco.org/new/en/education/themes/leading-the-international-agenda/education-for-sustainable-development/ education-for-sustainable-development/

http://www.iraqdinares.com/showthread.php?43458-2010-2014-FIVE-YEAR-NATIONAL-PLAN-Ministry-of-Planning

UNESCO, \& IRAQ (2003). UNESCO and Education in IRAQ Fact Sheet (28 March 2003). http://portal.unesco.org/en/ev.php-URL_ID=11216\&URL_DO=DO_TOPIC\&URL_SECTION=201.html

Weyman, T. (2003). Abu Khasib to Al Ah’qaf: Iraq Gulf War II Field Investigations Report, Uranium Medical Research Centre. http://www.umrc.net/os/downloads/Iraq report 1.doc

Wikipedia (2003).Violence against Academics in Post-Invasion Iraq. http://en.wikipedia.org/wiki/Violence_against_academics_in_post-invasion_Iraq

World Bank (2011). Iraq. http://data.worldbank.org/country/iraq 